\title{
Translocation and Transformation of Sucrose in the Wood of Prunus yedoensis II*
}

\author{
by Masao HasegawA** and Michi SHIRoyA**
}

Received December 11, 1967

\begin{abstract}
Labelled sucrose was administered to the cambial region of a Prunus yedoensis tree. The distribution of radioactivity and specific activity of flavonoids in the sapwood, inner sapwood and transition zone were measured. In sapwood, the ethyl acetate soluble portion has the highest radioactivity and in the transition zone, the ether soluble portion has the highest radioactivity. Flavonoids in the transition zone have a higher specific activity than those of the inner sapwood.
\end{abstract}

There are different hypotheses concerning the origin of phenolic compounds in woods. The precursors of the polyphenols in the transition zone are supposed to be sucrose or other sugars translocated from the leaves, and the phenolic compounds

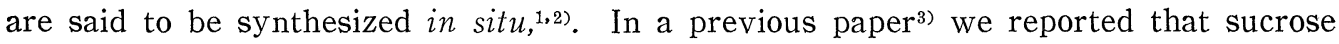
was translocated from the phloem to the transition zone through the ray cells and that polyphenols appeared to be synthesized in situ from the translocated sucrose.

Pridham et al. ${ }^{4)}$ have pointed out recently that absorbed polyphenols were translocated from the leaves to the stem through the phloem system. Sanderman et al.5) found glucose as the hydrolysis product in the transition zone of Picea abies.

In this report we deal with the transformation of labelled sucrose to polyphenols in Prunus wood.

\section{Experimental and Results}

The material used was a living trunk of Prunus yedoensis about 10 years old with a diameter of $8 \mathrm{~cm}$ and possessing a small amount of heartwood. The experiments were carried out in November. By means of a curved chisel $(1 \mathrm{~cm}$ diameter), and at a height of $90 \mathrm{~cm}$ above ground level three small holes were made in the bark so that the cambium was exposed. Labelled sucrose $(100 \mu \mathrm{c})$ dissolved in $1 \mathrm{~m} l$ water was placed in the holes, a few drops at a time, using an injection syringe. After two hours the solution was absorbed.

The tree was cut down two weeks later and sections were made as shown in Fig. 1. Each section was shaved with a knife and their weights were $78 \mathrm{~g}$ (C), $70 \mathrm{~g}$ (D) and $39 \mathrm{~g}$ (E). Each sample was extracted with $80 \%$ ethanol for 30 minutes (200 $\mathrm{m} l \times 3)$. The combined extract was evaporated to dryness and the residue was dissolved in water. The water soluble portion was extracted with ether and then ethyl acetate. The radioactivity of the three fractions was determined with a low back-

* Supported partly by a grant from the Ministry of Education.

** Department of Biology, Faculty of Science, Tokyo Metropolitan University, Setagaya-ku, Tokyo, Japan. 


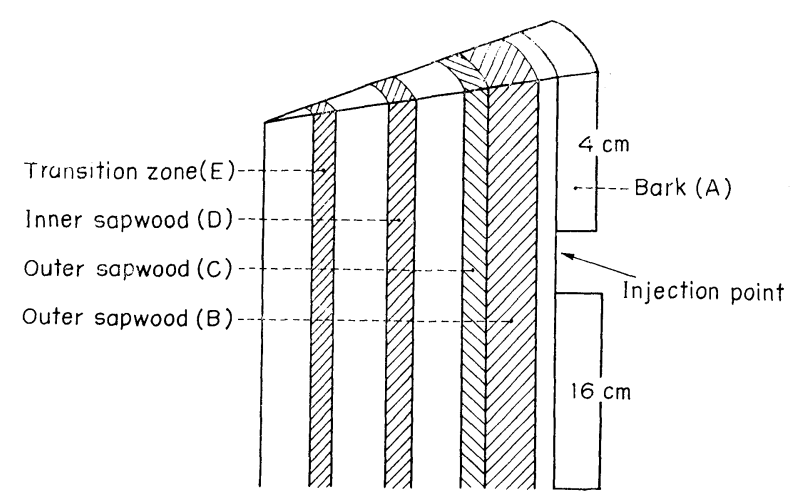

Fig. 1. The portions shaved from Prunus wood.

Table 1. Distribution of radioactivity (\%) in Prunus wood.

\begin{tabular}{crrrrr}
\hline Portions & A & B & C & D & E \\
\hline Fractions & & & & & \\
Ether soluble & 0.8 & - & 16.6 & 6.6 & 14.0 \\
Ethyl acetate & & & & & 6.7 \\
$\quad$ soluble & 0.7 & - & 24.8 & 84.6 & 79.0 \\
$\quad$ Water soluble & 98.8 & - & 58.2 & & 15360 \\
Total counts & & & 212900 & 58310 & \\
per min. & 5496220 & & & & \\
\hline
\end{tabular}

Table 2. The $R_{f}$ values and absorption maxima of phenolic compounds in Prunus wood.

\begin{tabular}{|c|c|c|c|}
\hline \multicolumn{4}{|c|}{$\mathrm{R}_{\mathrm{f}}$ Values } \\
\hline Compounds & BAW & $6 \%$ Acetic acid & Absorption maxima \\
\hline Prunin & 0.72 & 0.58 & $287 \mathrm{~m} \mu$ \\
\hline$d$-Catechin & 0.63 & 0.45 & $282 \mathrm{~m} \mu$ \\
\hline Dihydrokaempferol & 0.76 & 0.50 & $292 \mathrm{~m} \mu$ \\
\hline Kaempferol & 0.74 & 0.00 & $376 \mathrm{~m} \mu$ \\
\hline Naringenin & 0.80 & 0.32 & $287 \mathrm{~m} \mu$ \\
\hline
\end{tabular}

Table 3. The radioactivity ( $\mathrm{cpm} / \mathrm{mg}$ ) of the compounds obtained from various portions of Prunus wood.

\begin{tabular}{lrrr}
\hline \multicolumn{1}{c}{ Portions } & C & D & E \\
\hline Compounds & & & \\
Prunin & 209 & 21 & 23 \\
d-Catechin & 1176 & 77 & 131 \\
Dihydrokaempferol & 192 & 18 & 31 \\
Kaempferol & 176 & 23 & 33 \\
Naringenin & 172 & 14 & 24 \\
\hline
\end{tabular}


ground $2 \pi \beta$-counter. The results are shown in Table 1 .

The ethyl acetate soluble portions were concentrated, and one dimentional large scale paper chromatograms were prepared using BAW (n-butanol: acetic acid: water, $6: 1: 2 \mathrm{v} / \mathrm{v})$ as the developing solvent. The band corresponding to prunin $\left(\mathrm{R}_{\mathrm{f}}, 0.72\right)$ was eluted with $80 \%$ ethanol. After concentration, the residue was chromatographed using $6 \%$ acetic acid as developing solvent. The $\mathrm{R}_{\mathrm{f}}$ value of prunin was 0.58.

Kaempferol, dihydrokaempferol and $d$-catechin in the ether soluble fraction were obtained also by the same method described above. At the separation of naringenin in the ether soluble fraction, $6 \%$ acetic acid solvent was used as the first developing solvent and then BAW. $R_{f}$ values of these compounds are summarized in Table 2.

After elution of these compounds from the paper, the solution was concentrated to dryness using a rotatory evaporator. The residue was dissolved in $10 \mathrm{~m} l$ ethanol. The concentration of the compounds in the solution was measured spectrophotometrically (Hitachi automatic spectrophotometer EPS-II). The absorption maxima of these compounds are shown in Table 2. And the radioactivity was measured by a low background $2 \pi \beta$-counter (Japan Radio Company). The results are shown in Table 3. The Whatman No. 1 filter paper was used throughout these experiments.

\section{Discussion}

The distribution of radioactivity in the Prunus stem shows that the ability to form glycosides is larger in the outer sapwood than it is in the inner sapwood and transition zone (Table 1) and the degree of flavonoid formation is larger in the transition zone than it is in the inner sapwood (Table 3). The same results were obtained in the previous work ${ }^{3}$. If the polyphenolic compounds synthesized in leaves are translocated to the transition zone via the ray cells, the specific activity of the labelled polyphenols in each zone should decrease gradually from sapwood to transition zone. But Table 3 shows the specific activity of flavonoids in the transition zone to be higher than that in the inner sapwood. Especially, it is noticeable that polyphenols accumulate in the transition zone more than in inner sapwood of Prunus yedoensis ${ }^{6}$. Hence, these flavonoid compounds are not translocated from inner sapwood to the transition zone.

These results are in agreement with the conclusions drawn from the previous work, namely, polyphenolic compounds are synthesized in situ from sucrose or other sugars translocated from leaves.

\section{References}

1) Hillis, W. E., and Hasegawa, M., Phytochem. 2: 195 (1963).

2) Hillis, W.E., Humphreys, F. R., Bamber, R. K., and Carle, A., Holzforschung $16: 114$ (1962).

3) Hasegawa, M., and Shiroya, M., Bot. Mag. Tokyo $79: 595$ (1966).
4) Macleod, Norma J., and Pridham, J.B., Phytochem. 5 : 777 (1966).

5) Sanderman, W., Hausen, B., and Simatupang, M., Holzforschung 21 : 349 (1967).

6) Hasegawa, M., J. Jap. Forest. Soc., $40: 111$ (1958). 
長谷川正男・代谷 康：ソメイヨシノの材におけるショ糖の移動と変化 II.

前報に引き続いて, 師部に与えた放射性ショ糖が, 心材と辺材の境界領域, 抢よび辺材でどのようにフェ ノール物質にとりこまれるかを,ソメイヨシノの材を用いて試験した. 辺材では最外層から内部に向かって フェノール性物質の比放射能 $(\mathrm{cpm} / \mathrm{mg})$ は降下するが，白鮮帯で再び上昇する. このことから白鮮帯の ポリフェノールはその場所で, 移動してきた糖から合成されるものと考元られる.（東宗都立大学理学部生 物学教室) 